\title{
A Study on the Problems, Countermeasures and Reflections in the Practice of English Teaching in Junior Middle School — Based on the Teaching Practice of Jinfeng Experimental School
}

\author{
Xin Ma \\ School of Foreign Languages and Literatures, Chongqing Normal University, Chongqing, China
}

\begin{abstract}
In the current junior English teaching practice, there are existing some problems, so this paper is based on the teaching of Jinfeng experimental school, and discusses the problems in junior English teaching practice; designs the investigation report on the factors of middle school students' learning difficulties in the process of English learning; analyzes the investigation results; probes into the corresponding countermeasures, and it also makes some reflections on the English teaching of junior high school.
\end{abstract}

Index Terms-middle school English, teaching practice, problems, countermeasures

\section{Problems in English Teaching Practice}

In the process of English teaching practice, many problems have been found, which can be divided into two aspects: teachers' problems and students' problems. The specific contents are as follows:

\section{A. Teachers' Problems}

1. The teacher appreciates and illustrates focal points vaguely

For a novice English teacher, it is difficult to grasp key and difficult points of each unit of the textbook. Moreover, the teachers' incorrect and incomplete understanding of the key and difficult points further leads to the inadequate explanation and incomplete analysis of corresponding knowledge in English class, which also affects the English teaching effect and reduces the students' English classroom learning efficiency.

2. The teacher fails to build a positive English learning atmosphere

"In junior middle school English listening teaching, it is very important to build a good language environment and provide students with better listening training and learning opportunities, which is the main content of junior high school English listening teaching in the new situation" (Wang, 2016). However, in the current junior high school English teaching process, teachers fail to build a positive and effective English learning atmosphere, therefore, it's difficult for students to achieve the actual use of English or experience the process of English use, which also affects the effect of English learning.

3. The training and selection of English representative are inappropriate

The English representative should be the "helper" of the teacher, assisting the teacher to carry out English teaching better, but the cooperation with the representative is not positive in this teaching process. The main reasons are as follows: first of all, the English representative was selected last semester and in this semester, there are no new investigations and selections have been carried out. Secondly, the teacher fails to clearly inform the work of the representative in details, and there is less communication with him. Moreover, there is too much social work of the representative, and due to the carelessness of the English representative, he fails to pay enough attention to it, so he often fails to send and receive homework on time, which affects the development of English teaching activities to some extent.

4. The teacher pays little attention to individual differences of students

"At present, the learning level of students in English classroom teaching in junior middle school is uneven, their abilities are different, and the polarization phenomenon is also very different" (Yan, 2017). Students have their own differences, and each student's knowledge level and cognitive ability is also different. Therefore, in class, it is difficult for teachers to take care of all students, so teachers should actively carry out individual conversation and communication after class, so as to better appreciate the students' thoughts and learning status, and take into account the students' situation in the preparation process, and take care of more students and ensure the efficiency of English classroom teaching.

\section{B. Students' Problems}

1. Students lack interest and initiative in English learning 
Interest is the best teacher, but in the current English learning process, students generally are lack of interest in English learning. "As a second language, English generally appears in the entrance examination, which has no context in daily life, so students' motivation in English learning is relatively low" (Tang, 2019). Students lack interest and initiative in learning, so they will not learn English positively, which leads to the unsatisfactory English performance.

\section{Students' English learning habits and methods are inappropriate}

Some students have inappropriate English learning habits, for example: some students do not take notes in class; when encounter learning problems, they almost never actively ask the teacher about the problems. After class, some students fail to complete their homework in time, and will not review and consolidate what they learned in time. What's more, students' learning method is mechanical and ineffective, which needs to be improved urgently. For example, some students still use rote and mechanical memory methods when they memorize words, which is particularly time-consuming and inefficient for English learning.

\section{Students' negligence of classroom discipline and lack of self-discipline}

In the process of classroom teaching, most students generally lack the sense of rules and regulations and the discipline of class; therefore, most students in the classroom have ignored regulations and discipline completely. After the bell rings, students are still playing, chatting and whispering. When the teacher is teaching, students still have some bad behaviors, such as doing minor actions, passing notes, speaking, sleeping and so on. Some of the behaviors greatly affect the smooth development of classroom teaching activities.

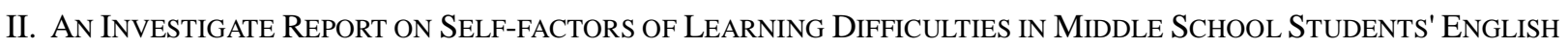 LEARNING PROCESS}

In order to better understand the students' English situation, the author uses the questionnaire of Wang Yangguang for reference, and combined with the actual English teaching situation, adds some questions, so as to better understand the students' needs, further improve the education and teaching methods, and enhance the teaching effect, and finally improve the quality of teaching.

\section{A. Investigation Background}

At present, many experts and scholars have made corresponding researches and explorations on the difficulties of middle school students' English learning, and have made some achievements. They have published many related papers and works, which are summarized mainly from the aspects of students' age, cognitive style, acceptance, social influence, etc.

\section{B. Purpose of Investigation}

This survey is mainly to investigate the difficult factors of students in the process of English learning through the questionnaire, so as to be able to carry out targeted teaching in later English teaching, and lead students to gradually break through the difficulties of English learning, so as to improve the efficiency of students' English learning.

\section{Respondents}

Grade seven and Grade eight students of Jinfeng experimental school in Chongqing Gaoxin District.

\section{Investigation Content}

There are 20 questions in the questionnaire. The contents of the questionnaire are: Students' current English scores, students' interest in English learning, students' enthusiasm for English learning, and students' suggestions for current English teaching, etc.

\section{E. Questionnaire}

\section{Attachment I}

\section{F. Questionnaire Analysis}

In this investigation, 70 students have been investigated, and they are all from Grade Seven or Eight, and the investigation has been carried out after the 5 months English teaching of the English teacher.

According to the investigation results, what we can know is that $55.71 \%$ of students are discontent with their English scores, and there are only $7.14 \%$ students think that they have comparative good English scores. Furthermore, there are only $8.57 \%$ students spend about or more than 2 hours in English learning, however, about $65.71 \%$ students spend half an hour in English learning, which is not enough for the after-school English learning. There are only $15.71 \%$ of students who will learn English actively after school, and about $67.14 \%$ of students will learn English positively. About $55.71 \%$ of students, the objective for them is to learn English is to use English in the future. About $35.71 \%$ of students are learning English to prepare for the Entrance Exams. About half of the students will make plans for English learning sometimes. There are 16 students that are about $22.86 \%$ of students who never review, make a summary or conclude what they have learned every day. $51.43 \%$ of students will sometimes communicate with other students on exchanging learning experience, but $35.71 \%$ of students almost never communicate with other students on study. About $61.43 \%$ of the students have some confidence in learning English well, but $14 \%$ of the students have no confidence in learning 
English well, and $55.71 \%$ of the students will try to learn English well with various methods.

In current English teaching, the most necessary three aspects that need to be improved are: the interest of English classroom teaching, the diversity of English classroom teaching activities and the diversity and richness of homework, accounting for $72.86 \%, 62.86 \%$ and $40 \%$ respectively. In the process of English learning, the students think that the most difficult aspects are: they can't understand the sentence meaning of complex sentences; they can't remember words and phrases, and they can't use what they have learned correctly and appropriately, which accounts for 77.14\%, 64.29\% and $52.86 \%$ respectively. The three aspects that students want to learn are: how to correctly understand sentence pattern, sentence pattern and sentence meaning; how to correctly spell and memorize words and phrases and how to apply what they want to learn to realize the flexible use of knowledge, accounting for $80 \%, 67.14 \%$ and $48.57 \%$ respectively. In the English test, the most difficult questions are: Text Completion, accounting for $64.29 \%$, followed by Cloze, Reading comprehension, Written Expression, all accounting for $51.43 \%$.

According to the analysis of the survey results, in the process of preparing class, the teacher should pay more attention to the interest of classroom teaching; the diversity of teaching activities, and develop more English teaching resources, so as to be able to have more abundant and diverse homework. At the same time, teachers should carry out teaching activities for students' learning difficulties, and lead students to gradually break through the difficulty of sentence meaning understanding, word memory and flexible use of knowledge. Moreover, teachers should combine the needs of students to teach students the aspects they want to improve, such as: correctly understand sentence patterns, sentence patterns and sentence meanings; effectively spell and memorize words and phrases; and correctly use the knowledge they have learned. Finally, teachers should combine the actual situation of the test; lead students to grasp the test points; master the skills and skills of each test question type, and gradually break through each type.

\section{Countermeasures of English Teaching Practice}

\section{A. Strengthen the Improvement of Teachers' Professional Teaching Skills}

Teachers should keep on learning so as to improve their knowledge level and professional teaching ability. According to Professor Liu Jie, "there are six standards for Teacher Professionalization: (1) the use of specialized knowledge and skills; (2) the long-term training and training; (3) the emphasis on the concept of service and professional ethics; (4) the enjoyment of effective professional autonomy; (5) the formation of a strong professional organization; (6) the need for continuous learning and study" (Liu, 2001). Therefore, teachers should constantly improve themselves from the above aspects, so as to achieve the improvement of teaching quality and the efficiency of classroom teaching.

\section{B. Improve the Interest and Diversity of Classroom Teaching Activities}

When teachers prepare for lessons and design teaching activities, they should pay attention to the interest and diversity of teaching activities. In addition, teachers should also pay attention to the interest of teaching language, teachers' language should be suitable for students' psychological characteristics, and appropriate inspiration ideas should be used to ignite the spark of students' wisdom. 'Teachers should use vivid language to attract students' attention and be good at illustrating abstract concepts concretely to stimulate students' interest in learning and activate students' thinking space to make them full of imagination and creativity" (Luo, 2013). Various teaching activities can also help students to concentrate on the activities and stimulate their thirst for knowledge.

\section{Cultivate Students' Subjective Initiative and Learning Habits}

Students are the main character of English teaching activities. Therefore, increasing students' initiative in English learning plays an indispensable role in improving English effect. "In English teaching, teachers should combine the actual situation, optimize and innovate teaching methods, enrich teaching forms, and activate the classroom atmosphere, so as to enhance the enthusiasm of students in English learning" (Tang, 2019). In addition, teachers should also correct the current bad habits of students, and cultivate students to develop good learning habits. For example, before class, the teacher should tell students that they should actively mark them if they don't understand the knowledge points, and then ask the teacher after class; build their own wrong notebook; summarize and reflect on what they have learned after class every day.

\section{Carry out English Reading, Recitation and Targeted Question Type Training}

English is a language in nature and a tool for communication. Therefore, teachers should actively carry out extra-curricular English reading activities and assign certain recitation tasks, so that students can read and memorize more and then broaden the way of English input. In addition, extracurricular English learning plays an important role in students' learning. "Extracurricular reading can not only improve students' grammar and perception in the text, but also well understand the language of the article" ( $\mathrm{Li}, 2015)$. According to the students' difficulties, we should carry out special exercises on the questions such as Text Completion and Written expression, so as to realize the directional improvement.

\section{E. Formulate the Reward and Punishment System of English Teaching}

The teacher should make a complete system of rewards and punishments when preparing lessons. Furthermore, the 
teacher ought to inform students the rewards and punishments in the first English class, and make sure that everyone has remembered them. Furthermore, the teacher should continuously improve the daily evaluation system during the process of teaching. "Teachers should change from summative assessment to formative assessment, and properly integrate the elements of authenticity assessment" (Ma, 2011).

\section{F. Improve the Evaluation System, and Timely Give Feedback}

The teacher should give timely feedback on students' behavior and learning. "Contemporary psychological research shows that promoting the unity of students' cognitive process and cognitive results is an important factor for students' effective learning. What's more, "classroom teaching should not only tell students "what is it", but also teach students "why", to help students get teaching results consistent with teaching objectives" (Yan, 2017), so that students can strengthen their positive behavior and weaken their bad behavior in time.

\section{Reflection on Middle School English Teaching Practice}

\section{A. Teachers Should Strengthen the Unity of Theory and Practice}

In current teacher's normal education, it emphasizes the instillation of theoretical knowledge of education and professional disciplines, so the deviation and poor practicability of teachers' own teaching competence make many teachers at a loss when they further the professional knowledge and then apply them to the education practice, and they are unable to meet the requirements of the new curriculum for teachers' quality. In order to change this situation, in teacher education, when we want to apply it to education practice, we are at a loss and can't adapt to the requirements of the new curriculum for teachers' quality. In order to change this situation, we should improve the ability of teachers to solve practical problems. "We should appropriately increase the opportunities for teachers to participate in curriculum experiments and curriculum development, advocate teachers to carry out "action research", improve the effectiveness of teachers' professional training, and so on, so as to improve the practical ability of teachers' own learning and teaching" (Wei, 2005).

\section{B. Make Clear the Main Body of Class, and Adopt Various Teaching Methods}

In the process of teaching, teachers should make clear the main position of students in the classroom teaching, so that students can actively and effectively participate in classroom activities, so as to achieve the teaching objectives. Moreover, teachers should also make clear their own leading position, have the ability to control the rhythm of the classroom, and deal with emergencies. In addition, teachers in junior middle school should devote themselves to cultivating students' English core literacy. "In English teaching practice, they should adopt various teaching methods to effectively stimulate students' interest in English learning and realize the effective cultivation of students' English core literacy" (Fu, 2018). On the basis of the teaching method, junior middle school English teachers can adopt a variety of teaching methods, such as situational teaching method, task-based teaching method, group discussion teaching method, to effectively improve the effect of junior middle school English Teaching.

\section{Keep Improving in Teaching Practice and Strengthen Teachers' Self-reflection}

In practical teaching, teachers will find that there is a certain gap between theory and practice. Therefore, teachers should continue to learn and improve themselves in practice, and finally realize the effective combination of theory and practice. In addition, teachers should also actively reflect on themselves, constantly reflect on their own improper place in the education and teaching work, and actively improve the teaching work. "The development of teacher reflection not only includes reflection on the purpose, goal and values of education and teaching, the outlook on students and the outlook on teachers and students, which is not only an important way for teachers to promote theory and transform practice, but also includes their own teaching practice" (Wei, 2005). The teacher reflection should also include the selection of content, the selection of methods, the interaction between teachers and students, the treatment of educational wit, the reflection on problems, the ways for avoiding the problems, etc.

\section{CONCLUSION}

Effective teaching should be based on the correct understanding and rational analysis of students, so as to further achieve the teaching objectives. Based on the author's teaching practice in Jinfeng experimental school, this paper explains the students' problems in the process of English learning, designs a report on the investigation of students' self-factors of learning difficulties in the process of English learning, investigates the students of Grade seven and eight in Jinfeng experimental school, analyzes the students' self-factors of learning difficulties, and further puts forward the corresponding countermeasures. It aims to make a breakthrough in future English teaching practice and make the continuous improvement. However, there are also some shortcomings in this paper. Firstly, the number of respondents is small, and there are some deviations in the survey data. Nevertheless, this paper is a preliminary exploration of the English teaching in junior middle schools which is short of theory basis. Therefore, the combination of theory and teaching practice should be continuously explored and carried out in the future research. 
APPENDIX

1. Your English score is
A. poor
B. general
C. good

\section{$?$}

2. Do you like English?
A. like
B. dislike
C. average

3. Do you think English is interesting?

A. Interesting B. boring C. general

4. How long is your spare time that spends in English study?

A. half hour B. one hour C. two hours and above

5. Do you learn English actively after class?

A. yes B. no C. sometimes

6. Do you actively participate in thinking and answer questions in class?

A. yes B. no C. sometimes

7. Do you use other English learning materials after class?

A. yes B. no C. sometimes

8. Why do you study English?
A. entrance examination
B. English can be used in later life
C. studying abroad and others

9. Do you make and implement plans for English learning?

A. often B. sometimes C. basically not

10. How often do you review, sort out and summarize English knowledge?

A. always doing B. sometimes $\mathrm{C}$. basically not

11. How often do you exchange learning experience with teachers or classmates?

A. often B. sometimes C. basically no

12. Are you confident in learning English well?

A. very confident B. no confidence C. some confidence

13. Do you usually try to learn English well in various ways?

A. yes B. no C. sometimes

14. How do you usually finish the English homework?

A. Finish it conscientiously and strive to make no mistakes.

B. Hope to finish the job in the least time.

C. Work often can't be completed on time with quality and quantity guaranteed.

15. When you encounter difficulties in English learning, or when you fall behind in English, you will $?$

A. Overcome all difficulties, encourage myself and catch up.

B. At first, I had a strong motivation to learn, but for various reasons, I was slowly slack.

C. It doesn't matter. Just muddle along.

16. In English learning, can you work hard to overcome shyness and anxiety?

A. can do B. sometimes can do C. can't do

17. In current English teaching, which aspects need to be improved?

A. The interest of English classroom teaching.

B. The diversity of English classroom teaching activities.

C. The reward and punishment system of English teaching.

D. Professional teaching skills of English teachers.

E. The diversity and richness of homework after class.

F. Early self-study of English reading recitation.

18. In the process of learning English, which parts are the most difficult to do?

A. It is difficult to remember words and phrases.

B. Unable to understand the meaning of complex sentences.

C. Can't use what you have learned and use what you have learned correctly.

D. It is difficult to finish the homework after class.

E. Communicate in English.

F. Recite and read English.

19. In the current English learning, what kind of knowledge and skills do you want to learn?

A. How to spell and memorize words and phrases correctly.

B. How to understand sentence pattern, sentence pattern and sentence meaning correctly.

C. How to communicate in English.

D. How to use English words to make sentences and layout.

E. How to apply the knowledge and realize the flexible use of knowledge.

20. Which question types are the most difficult in English test? 

A. Listening.
B. Single choice.
C. Cloze.
D. Reading comprehension.
E. Oral communication.
F. Task based reading.
G. Text Completion.
H. Written expression.

\section{REFERENCES}

[1] Fu Mingxiu. (2018). Problems and measures in junior middle school English Teaching. Curriculum education research, 16:95-96.

[2] Li Guishen. (2015). Problems and Countermeasures in English grammar teaching in junior middle school. Learning Weekly, 33:127-128.

[3] Liu Jie. (2001). Professional specialization of teachers and normal education in China. Journal of Tianjin Normal University (social sciences edition), (2):75-80.

[4] Luo Qiong. (2013). Research on English teaching problems and Countermeasures in junior high school under the background of new curriculum reform. Education and teaching forum, 36:85-86.

[5] Ma Junbo. (2011). Public English Teaching in Higher Vocational Colleges: Problems and solutions. Vocational education research, 03:111-113.

[6] Tang Wanmin. (2019). Research on English classroom teaching strategies in the context of quality education. New curriculum research, 24:108-109.

[7] Wang Hong. (2016). Problems and solutions of English Listening Teaching in junior middle school under the new situation. Chinese after-school education, 15:113-115

[8] Wang Yangguang. (2020). an investigation report on the self-factors of English learners with difficulties. Xiangshui Yunhe middle school http://www.doc88.com/p-974197853369.html (accessed 5/26/2020).

[9] Wei Yanju. (2005). Professional development of primary and secondary school teachers in the context of basic education curriculum reform. Shandong Normal University.

[10] Yan Rui. (2017). Analysis of problems in English classroom teaching and Research on countermeasures. Research results of research on Teachers' teaching ability development, 3: 551-560.

Xin Ma was born in Chongqing, China in 1993. She received her Bachelor degree in English from Yangtze Normal University in 2017.

She is currently a postgraduate student in the School of Foreign Languages, Chongqing Normal University, Chongqing, China. Her research interests include English language teaching and American literature. 